\title{
The impact of residential septic tanks on soil water infiltration and groundwater contamination in Duhok city
}

\author{
Shawkat Ahmed Kochary ${ }^{1}$, Lamyaa M. Hasan Alnaqshabandi2, Hassan Ramadhan Abdo ${ }^{3}$ \\ ${ }^{1}$ College of Engineering, University of Duhok, Duhok, Kurdistan Region - Iraq \\ 2,3Directorate of Environment, Duhok, Kurdistan Region - Iraq
}

\begin{abstract}
This study was conducted to assess the impact of septic water on soil water infiltration in Duhok city potentially contaminating regional groundwater through designing a large-scaled laboratory physical model of vertical flow direction packed homogenously with silt-Clay soil. The designed model was supplied with newly collected septic water. With steady-state flow condition, the model was run, water samples were collected and analyzed weekly. Various parameters and constituents that may influence soil structure and water infiltration were examined including : Electrical conductivity, sodium, calcium, magnesium, carbonate, bicarbonate, residual sodium carbonate (RSC), pHc and adjusted sodium absorption ratio (adj. SAR). For assessing groundwater quality, bacteriological analysis were conducted. Analytical results were used to estimate the examined parameters and predict their future trends. Results revealed that electrical conductivity (EC) was accumulating until it reaches the carrying capacity. Sever hazard of (RSC) was detected within 25 meter depth. Average pHc was 6.74 indicating the tendency of lime $\left(\mathrm{CaCO}_{3}\right)$ to precipitate from applied septic water. adj. SAR for port A and port B were 11.1 and 8.65 respectively which, caused severe soil deterioration, but on the other hand helped in decreasing the rate of contaminants transport for treatment within the soil before reaching the groundwater. Results of bacteriological analysis indicated that groundwater shallower than 31 meter was contaminated by fecal and total coliform bacteria. This study helped local authorities in establishing precaution strategies of groundwater management to protect public health.
\end{abstract}

KEYWORDS : Septic tanks, Soil water infiltration, Groundwater, pHc , adj. SAR.

\section{INTRODUCTION}

Groundwater contamination is the most serious threat to human health and the environment (Holland, 1992). However, the most frequently reported cause of groundwater contamination associated with waterborne diseases by bacteria and viruses are septic systems (Yates, 1985) with the most influencing factor of high density (USEPA, 1997). As many cases of groundwater contamination and water-related diseases have reported in Duhok city (as area of investigation), the public became more concern about its quality by septic systems specifically in the absence of governmental regulation (i.e. improper construction, high density, and poor maintenance). Therefore, this research was conducted to assess the impact of septic water of non- regulated septic systems of Duhok city on soil water infiltration potentially contaminating regional groundwater. Problems with water infiltration are usually associated with using water of either low salt content or relatively high sodium to calcium and

Academic Journal of Nawroz University

(AJNU) Volume 7, No 4 (2018).

Regular research paper : Published 21 December 2018

Corresponding author's e-mail : shawkat@uod.ac

Copyright (2017 Shawkat Ahmed Kochary1, Lamyaa M.

Hasan Alnaqshabandi2, Hassan Ramadhan $\mathrm{Abdo}^{3}$.

This is an open access article distributed under the Creative

Commons Attribution License. magnesium content. Some water constituents can cause severe soil permeability problems like the excessive quantities of sodium (or shortages of calcium and magnesium), carbonates and bicarbonates under certain conditions in addition to pure water (i.e. low salt water), which rapidly dissolve all sources of calcium from surface soils, breakdown and seal (after dispersion) resulting in poor air and water infiltration. Excess sodium in natural soils can damage its structure and prevent infiltration of air and water resulting in reduction in soil aeration and permeability (Naseem et al. 2012). High concentrations of sodium ions in the water are related to human activities such as industrial effluents, agricultural chemicals, leaching from landfills, and septic tanks effluent, which is a potential source for both chemical and microbial contaminants that need to be controlled to prevent the degradation of its quality. Microbial contamination usually considers by presence or absence of total or fecal coliform bacteria. Total coliform includes fecal coliform bacteria such as (E. coli) and other types that are naturally found in the soil while fecal coliform bacteria exist in the intestines of human and warm blooded animals. The presence of total coliform bacteria in the water does not necessarily indicate its contamination by fecal waste. However, the presence of fecal coliform indicates contamination by fecal material (feces) of human waste or animal droppings which, causes serious illness to human. 


\subsection{Salinity}

The severity degree of soil dispersion and flocculation cannot be designated by sodium adsorption ratio only without considering its salinity which, is often expressed as electrical conductivity (EC), which depends on the nature of the dissolved ionized substances, their actual and relative concentrations, and the temperature at which the measurement is made (Kochary et al. 2017). Electrical conductivity of regular water increases $2-3 \%$ per $1^{\circ} \mathrm{C}$ water temperature increment, while for pure water; it increases approximately $5 \%$ per $1{ }^{\circ} \mathrm{C}$ temperature increment (Zaidi and Pal, 2015). Electrical conductivity provides a rapid indication of total dissolved solids (TDS) contents in water, which is the measure of dissolved organic matters and inorganic chemical constituents (Kochary, 2017). EC and TDS may be converted to each other as: TDS $(\mathrm{mg} / \mathrm{L}$ or $\mathrm{ppm})=0.64 \times \mathrm{EC}(\mu \mathrm{S} / \mathrm{cm})($ Deshpande and Aher, 2012).

\subsection{Sodicity}

It is the effect of water on the physical and chemical properties of soil due to sodium accumulation. In other words it is the amount of exchangeable sodium ions in water (or soil). In water, assessing the sodicity hazard include the measure of Residual Sodium Carbonate (RSC) and Sodium Adsorption Ratio (SAR). Sodic soils have high exchangeable sodium, high $\mathrm{pH}$, and low calcium and magnesium which, all together cause the soil to disperse. Dispersion of soil particles destroys its structure and reduces water movement and aeration into or through it by clogging its pore spaces. In general, the soil terms sodic when the exchangeable sodium percentage (ESP) in top $1 \mathrm{~m}$ of it is greater than $6 \%$ (Naidu et al. 1995). Sodic soils often have a black color with greasy-looking surface due to dispersion of organic matter (Blaylock, 1994). The use of saline water may reduce the level of soil dispersion (in the short term) due to flocculation of clay particles. However, with insufficient leaching rate, sodium would accumulate in the soil making it more sodic and hard to manage (Blaylock, 1994).

\subsection{Residual sodium carbonate (RSC)}

It is the amount of sodium carbonate and sodium bicarbonate in the water. RSC is said to be present in water sample when the concentration of carbonate $\left(\mathrm{CO}_{3}{ }^{-}\right)$and bicarbonate $\left(\mathrm{HCO}_{3}{ }^{-}\right)$ions exceeds the concentrations of calcium $\left(\mathrm{Ca}^{+2}\right)$ and magnesium $\left(\mathrm{Mg}^{+2}\right)$ ions. RSC are usually expressed as mill equivalents per liter (meq/L) of sodium carbonate. Extended use of water with high RSC in clay and silt soil will lead to sodium accumulation resulting in excess soil salinity and soil dispersion (structural damage) which, severely reduces its infiltration capacity. Where all concentrations are in meq/L, RSC index may be calculated as :
RSC index $=\left[\mathrm{HCO}_{3}{ }^{-}+\mathrm{CO}_{3}{ }^{=}\right]-\left[\mathrm{Ca}^{+2}+\mathrm{Mg}^{+2}\right]$ Eq. (1.1)

1.4 Sodium adsorption ratio (SAR)

Is a relative concentration of sodium to both of calcium and magnesium in the water extract from a saturated soil paste (Horneck et al. 2007). In general, SAR uses to predict the potential of accumulated sodium in the soil primarily at the expense of calcium and magnesium as a result of continuous use of sodic water. In other words, it uses to assess the water infiltration problems caused by sodium accumulation $\mathrm{Na}^{+}$in the soil with relation to the combination of $\mathrm{Ca}^{+2}$ and $\mathrm{Mg}^{+2}$. Water with SAR greater than three considers sodic of potential hazard to soils as they are likely to disperse (i.e. break down into individual clay particles that block pore spaces) resulting in poor water infiltration and slow internal drainage. If the dispersion occurs in the subsoil, the soil may become totally impermeable (Hillel, 2013). However, this type of permeability problems is nowadays evaluated using a new adjusted sodium adsorption ratio (adj. SAR) developed by the U.S. Salinity Laboratory (USSL), which considers the original SAR calculation, the effect of carbonate/bicarbonate concentrations in addition to $\mathrm{Ca}^{+2}$ and $\mathrm{Mg}^{+2}$ through a theoretical and calculated $\mathrm{pHc}$ value added to the SAR. The concentration of bicarbonate $\left(\mathrm{HCO}_{3}{ }^{-}\right)$in water and soil is important for its relation with calcium and magnesium as they both have a tendency to react with it and precipitate as calcium carbonate $\left(\mathrm{CaCO}_{3}\right)$ and magnesium carbonate $\left(\mathrm{MgCO}_{3}\right)$. They are the same compounds as the active portions of lime and have a similar effect on soil as lime. The adjusted sodium adsorption ratio (adj. SAR) is now calculated as :

$$
\text { adj. SAR }=\frac{\mathrm{Na}^{+}}{\sqrt{\frac{\mathrm{Ca}^{+2}+\mathrm{Mg}^{+2}}{2}}}[1+(8.4-\mathrm{pHc})] \quad \text { Eq. }(1.2)
$$

Where :

$\mathrm{pHc}$ is a theoretical, calculated $\mathrm{pH}$ of the supplied water in contact with lime and at equilibrium with soil $\mathrm{CO}_{2}$. $\mathrm{pHc}$ of the supplied water may be calculated as: $\mathrm{pHc}=\left(\mathrm{pK}_{2}-\mathrm{pK}_{\mathrm{c}}\right)+\mathrm{p}\left(\mathrm{Ca}^{+2}+\mathrm{Mg}^{+2}\right)+\mathrm{pAlk}$ Eq. (1.3) Where:

$\mathrm{pK}_{2}, \mathrm{pK}_{\mathrm{c}}$ and $\mathrm{pAlk}$ are the negative logarithms of the second dissociation equilibrium constant of carbonic acid, the solubility equilibrium constant for calcite, the alkalinity respectively. $\left(\mathrm{pK}_{2}-\mathrm{pK}_{\mathrm{c}}\right)$ may be obtained from totaling $\left(\mathrm{Ca}^{+2}+\mathrm{Mg}^{+2}+\mathrm{Na}^{+}\right)$, Alk is a total base of $\left(\mathrm{CO}_{3}{ }^{+}+\mathrm{HCO}_{3}{ }^{-}\right)$, concentrations of $\mathrm{Ca}^{+2}, \mathrm{Mg}^{+2}, \mathrm{Na}^{+}, \mathrm{CO}_{3}{ }^{2}$ and $\mathrm{HCO}_{3}$ are all in meq/L. pHc measures the tendency of water to deposit or dissolve lime in/from the soil (Carrow and Duncan, 1998). pHc values above 8.4 indicate the tendency of dissolved lime from the soil through which, the water moves while its values below 8.4 indicate the tendency of lime to precipitate from supplied water (Deshpande and Aher, 2012). In this study, $\mathrm{pHc}$ values was calculated to investigate the 
tendency of lime to either dissolve from the soil, through which the septic water moves, or to precipitate from septic water and deposit in packed soil of designed model.

\subsection{Salinity/Sodicity relationship (EC/SAR)}

The use of water with high sodium concentration is likely to affect soil physical properties (e.g. permeability) as sodacity has dispersive effects on soil particles under various salinity/ sodicity combinations. Therefore, and in order to assess the impact of septic

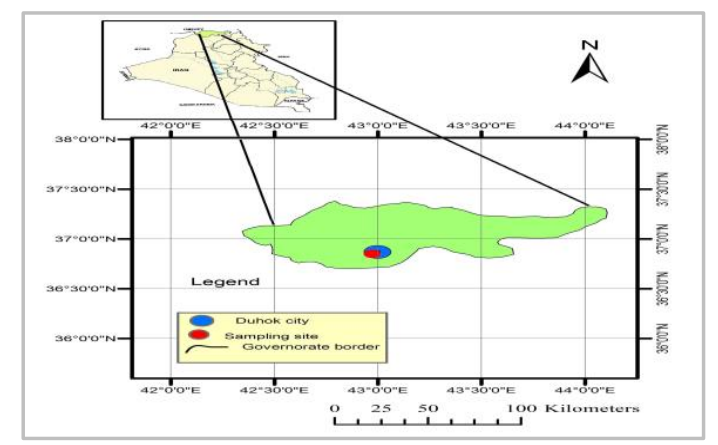

water on soil water infiltration rate, it is necessary to consider the effect of water salinity (EC) together with its sodacity (SAR).

\section{Materials and Methods}

\subsection{Study Location}

Duhok city locates at northwest part of Kurdistan region of Iraq with geological coordinates of $36^{\circ} 50^{\prime} 00^{\prime \prime}-$ $36^{\circ} 547^{\prime} 40^{\prime \prime}$ Latitudes and $42^{\circ} 52^{\prime} 00^{\prime \prime}-43^{\circ} 04^{\prime} 44^{\prime \prime}$ Longitudes. It encompasses approximately $107 \mathrm{~km}^{2}$. See Fig.1.

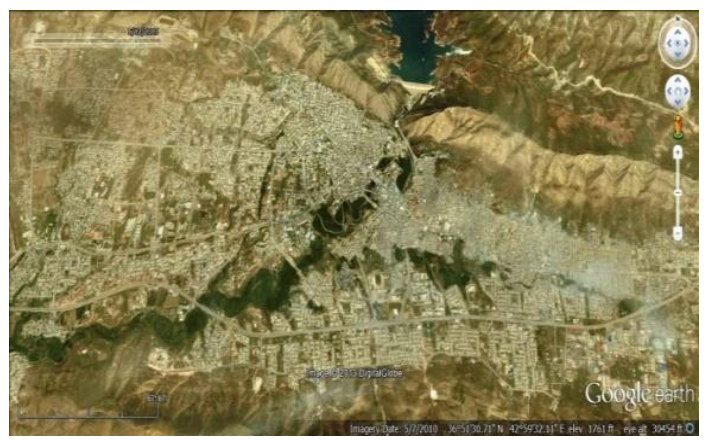

Fig (1) : Sketch of the site location and Satellite aerial view of area of investigation

\subsection{Preliminary Tests}

Prior to model design, necessary preliminary soil tests were performed from a non-residential area and mostly following the standard methods for the examination of water and wastewater (APHA, 1995) to specify soil properties to be applied in the designed experimental physical model. The tests included: In-situ bulk and dry soil densities, optimum water content that corresponds to optimum dry density, permeability specific gravity test. The soil used for packing material was classified as Low plasticity silt-Clay soil (CL) according to unified soil classification system plasticity chart (USCS) for laboratory classification of fine-grained soil.

\subsection{Design of Physical Model}

To conduct this study, it was proposed to design a large-scaled (1:50) physical vadose model (PVM) of 197x $120 \times 9.7 \mathrm{cms}$ for height, width, and depth, respectively with vertical flow direction in the laboratory to represent 100 meter of lithology of area of investigation. The model is to be packed with silt-Clay soil at homogenous manner and run with very recent raw septic water (from a septic tank) as exclusive source of contaminants. To ensure water samples collection under gravitational force (i.e. increasing the hydraulic conductivity), the texture of packing material was modified by replacing $20 \%$ (by weight) of silt-Clay soil with fine sand, whose particles passed sieve \#30 and remained on sieve \#40. Thus, sand/clay ratio of 20/80 percent (by weight) was adopted and the average actual hydraulic conductivity of modified packing texture was $\mathrm{k}$ act $=1.79 \times 10^{-4} \mathrm{~cm} / \mathrm{sec}$ (Measured through model draining process). The model was packed with one homogeneous layer ( of total of $377.5 \mathrm{kgs}$ of well-mixed sand/clay texture of $17.12 \mathrm{kN} / \mathrm{m}^{3}$ dry density. To improve flow conditions and prevent fine-graded materials to permeate out of the model, a drain filter was designed according to the criteria established by (Ministry of Agriculture and Food, British Columbia, 2000) for designing drain filters and envelopes (Kochary et al. 2017). Eight sampling ports were installed at 12.5, $37.5,62.5,87.5,112.5,137.5,162.5,187.5 \mathrm{cms}$ from top and named as Port A through Port $\mathrm{H}$ to represent groundwater levels at $6.25,18.75,31.25,43.75,56.25$, $68.75,81.25,93.75 \mathrm{~m}$ respectively. This study interested in the first five Ports: Port A, Port B, Port C, Port D, and Port $\mathrm{E}$ which, represented five different groundwater levels (up to $56.25 \mathrm{~m}$ underground). To monitor the hydraulic gradient and model internal pressure, eight piezometers were installed at sampling port levels. A storage chamber septic tank with five openings was designed, constructed, and put on top of the model. Fig.2. represents a non-scale sketch and a 1:50 scale physical model design. 

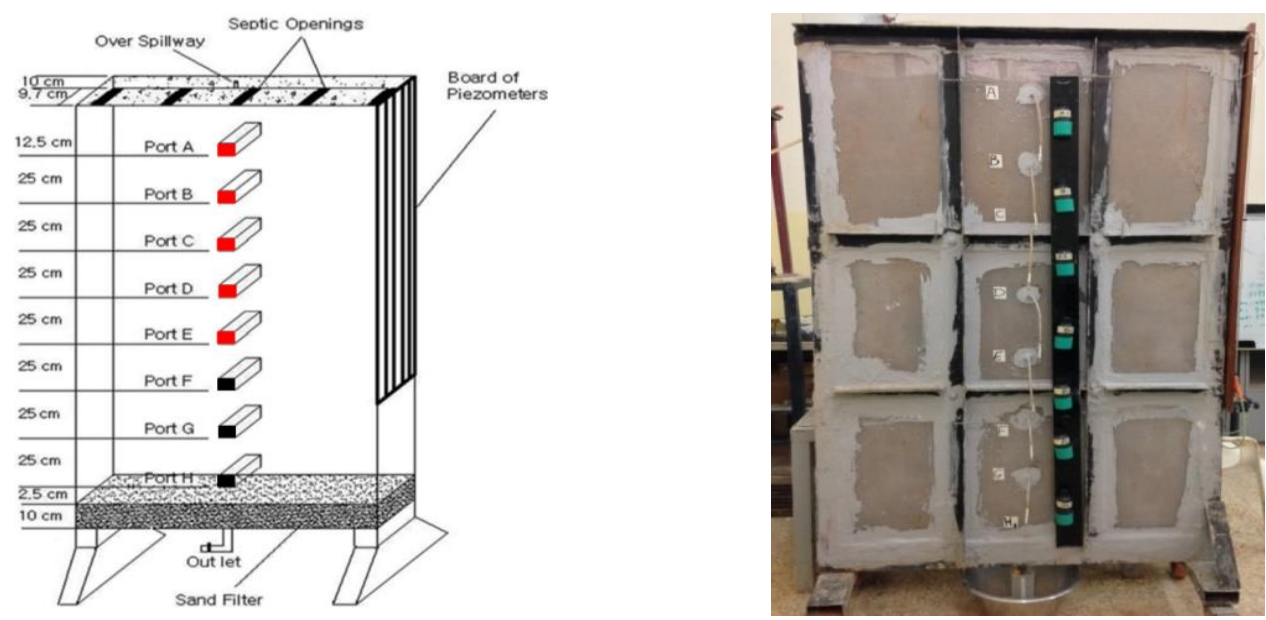

Fig (2) : A non-scaled sketch and a 1:50 scale of physical model design

\subsection{Process of Model Running}

After packing process completed, the model was drained from dissolved material contents using tap water for a period for four weeks until the electrical conductivity of water at inlet and outlet have reached a negligible level of difference (i.e. EC in $\approx \mathrm{EC}$ out). Very recent septic water was collected from a septic tank, filtered twice for suspended materials removal, packed into plastic bottles of 1.5-liter, and refrigerated at $4{ }^{\circ} \mathrm{C}$ in the dark. In running the model, a bottle of septic water was added to the top of model daily, and within $4 \mathrm{hrs}$, sets of $8 \times 180 \mathrm{ml}$ samples were collected from sampling ports. Model running process lasted in 91 days and basic rules of sampling, handling, preservation, and transportation were consistently followed.

\subsection{Methods of Analysis}

Water samples were collected on daily basis. However, analyzed weekly and mostly following the standard methods. Immediately upon samples collection, electrical conductivity (EC) were determined using a portable Horiba U-10 water quality meter. Total dissolve solids (TDS) were determined using (HI 9813$5 \mathrm{~N})$, soluble sodium $\left(\mathrm{Na}^{+}\right)$by using flame photometer (PFP-7 Jenway Model) according to (Ryan et al. 2007), carbonate $\left(\mathrm{CO}_{3}{ }^{-}\right)$and bicarbonate $\left(\mathrm{HCO}_{3}{ }^{-}\right)$by titration method with $(0.01 \mathrm{~N}) \mathrm{H}_{2} \mathrm{SO}_{4}$, calcium ion $\left(\mathrm{Ca}^{+2}\right)$ and magnesium ion $\left(\mathrm{Mg}^{+2}\right)$ by using flame atomic absorption spectrophotometer (FAAS-7000- Shimadzu Model). For microbiological examination (total and fecal coliforms), samples were collected on bi-weekly basis, placed in the ice immediately upon collection, and analyzed within $24 \mathrm{hrs}$ using multiple-tube fermentation technique (SM 9221B and SM 9221C)/approved by standard methods committee, A-E, 1999). Results of sodium, calcium, magnesium, carbonate, and bicarbonate were used to calculate the residual sodium carbonate (RSC), pHc, and adjusted sodium absorption ratio (adj. SAR). In calculating the $\mathrm{pHc}$ values, the corresponding values of its elements were determined using the following regressions: $y=2 * 10^{-6} x^{3}-0.0003 x^{2}+$ $0.0166 \mathrm{x}+2.1296$ with $\left(\mathrm{r}^{2}=0.9922\right)$ for $\left(\mathrm{pk}_{2}-\mathrm{pk}_{\mathrm{c}}\right), \mathrm{y}=-$ $0.435 \ln (\mathrm{x})+3.298$ with $\left(\mathrm{r}^{2}=1\right)$ for $\mathrm{p}\left(\mathrm{Ca}^{+2}+\mathrm{Mg}^{+2}\right)$, and $\mathrm{y}=$ $-0.435 \ln (x)+2.9982$ with $\left(r^{2}=1\right)$ for pAlk.

\section{Results and Discussion}

Analytical results of water samples are presented in Table 1 while descriptive statistics of all analytical data are summarized in Table 2 . The results will be individually discussed.

TABLE (1) : The Average of Chemical Composition of Water Samples ${ }^{1}$

\begin{tabular}{|c|c|c|c|c|c|c|c|c|c|c|c|c|}
\hline \multicolumn{2}{|c|}{ Parameter } & EC & TDS & $\mathrm{Na}^{+}$ & $\mathrm{Ca}^{+2}$ & $\mathrm{Mg}^{+2}$ & $\mathrm{CO}_{3}{ }^{-2}$ & $\mathrm{HCO}_{3}{ }^{-}$ & $\mathrm{RSC}^{2}$ & $\mathrm{SAR}$ & $\mathrm{pHc}$ & adj.SAR $^{3}$ \\
\hline $\begin{array}{c}\text { Locati } \\
\text { on }\end{array}$ & $\begin{array}{c}\text { Depth } \\
(\mathrm{cm})\end{array}$ & $\mathrm{mS} / \mathrm{cm}$ & $\mathrm{ppm}$ & \multicolumn{8}{|c|}{} & \multicolumn{3}{|c|}{} \\
\hline Port A & 12.5 & 4.58 & 2934 & 9.23 & 4.88 & 7.39 & 1.42 & 13.43 & 2.58 & 3.71 & 6.43 & 11.10 \\
\hline Port B & 37.5 & 4.11 & 2631 & 7.64 & 5.16 & 8.96 & 1.34 & 12.12 & -0.66 & 2.89 & 6.40 & 8.65 \\
\hline Port C & 62.5 & 2.51 & 1604 & 4.53 & 4.47 & 10.86 & 0.82 & 12.77 & -1.74 & 1.67 & 6.34 & 5.09 \\
\hline Port D & 87.5 & 1.82 & 1168 & 2.51 & 4.14 & 9.85 & 0.71 & 9.16 & -4.11 & 0.95 & 6.52 & 2.76 \\
\hline Port E & 112.5 & 1.59 & 1017 & 1.71 & 3.89 & 8.86 & 0.63 & 8.14 & -3.98 & 0.67 & 6.60 & 1.90 \\
\hline
\end{tabular}

1 Water samples were collected and analyzed weekly from five different depths (i.e. Ports of designed model) for 91days period. ${ }^{2}$ RSC was determined using Eq. (1.1). ${ }^{3}$ adj. SAR was determined using Eq.(1.2). pHc was determined using Eq. (1.3). 
TABLE (2) : Summary of Statistics For Analytical Data.

\begin{tabular}{|c|c|c|c|c|c|c|c|c|c|c|c|c|c|c|c|c|c|c|c|c|}
\hline \multirow{2}{*}{ Parameter } & \multicolumn{4}{|c|}{ Port A } & \multicolumn{4}{|c|}{ Port B } & \multicolumn{4}{|c|}{ Port C } & \multicolumn{4}{|c|}{ Port D } & \multicolumn{4}{|c|}{ Port E } \\
\hline & Max & Min & Mean & SD.s & Max & Min & Mean & SD.s & Max & Min & Mean & SD.s & Max & Min & Mean & SD.s & Max & Min & Mean & SD.s \\
\hline EC $\mathrm{mS} / \mathrm{cm}$ & 4.87 & 4.23 & 4.58 & 0.21 & 4.66 & 3.50 & 4.11 & 0.29 & 2.98 & 1.76 & 2.51 & 0.34 & 2.26 & 0.68 & 1.82 & 0.41 & 1.98 & 0.51 & 1.59 & 0.42 \\
\hline TDS ppm & 3119 & 2715 & 2934 & 134 & 2985 & 2239 & 2631 & 187.2 & 1909 & 1124 & 1604 & 219.4 & 1444 & 433 & 1168 & 261.3 & 1264 & 317 & 1017 & 271.7 \\
\hline $\mathrm{Na}^{+} \quad \mathrm{Meq} / \mathrm{L}$ & 15.1 & 4.72 & 9.23 & 3.13 & 11.57 & 4.09 & 7.64 & 2.07 & 6.88 & 1.91 & 4.53 & 1.85 & 4.12 & 0.72 & 2.51 & 1.18 & 3.09 & 0.55 & 1.71 & 0.87 \\
\hline $\mathrm{Ca}^{+2} \mathrm{Meq} / \mathrm{L}$ & 7.60 & 3.04 & 4.88 & 1.25 & 7.25 & 3.37 & 5.16 & 0.95 & 5.28 & 3.27 & 4.47 & 0.73 & 4.97 & 2.14 & 4.14 & 0.80 & 4.83 & 1.77 & 3.89 & 0.83 \\
\hline $\mathrm{Mg}^{+2} \mathrm{Meq} / \mathrm{L}$ & 10.3 & 4.44 & 7.39 & 1.84 & 13.15 & 6.33 & 8.96 & 2.34 & 13.63 & 8.36 & 10.86 & 2.13 & 13.67 & 2.99 & 9.85 & 2.76 & 11.73 & 2.47 & 8.86 & 3.05 \\
\hline $\mathrm{Co}^{-2} \mathrm{Meq} / \mathrm{L}$ & 3.60 & 0.00 & 1.42 & 1.00 & 3.60 & 0.00 & 1.34 & 1.18 & 2.40 & 0.00 & 0.82 & 0.67 & 2.00 & 0.00 & 0.71 & 0.51 & 1.00 & 0.00 & 0.63 & 0.27 \\
\hline $\mathrm{HCO}_{3} \cdot \mathrm{Meq} / \mathrm{L}$ & 27.2 & 6.00 & 13.43 & 5.82 & 23.4 & 8.00 & 12.12 & 4.01 & 18.0 & 9.6 & 12.77 & 2.29 & 13.0 & 3.2 & 9.16 & 2.71 & 10.8 & 2.6 & 8.14 & 2.66 \\
\hline
\end{tabular}

With regards to electrical conductivity (EC) and total dissolved solids (TDS) the results of this study revealed that they both were in continuous accumulation in all interested model Ports to reach the carrying capacity of silt-Clay soil and depending mainly on the distance from the source of applied septic water (i.e. from top of model) see Fig.3. Mean values of TDS were 2934, 2631, and $1604 \mathrm{ppm}$ for Port A, Port B, and Port C respectively indicating that septic water contains sufficient dissolved organic matters and inorganic chemical constituents while the mean values of EC were $4.58,4.11$, and $2.51 \mathrm{mS} / \mathrm{cm}$ for Port A, Port B, and Port $C$ respectively which, indicate that septic water contains sufficient salts to represent a salinity hazard ( $\geq 2.250$ $\mathrm{mS} / \mathrm{cm}$ according to irrigation water quality index) and it considers unsuitable for irrigation purposes that most likely to cause groundwater contamination if the soil has flocculated by common cations (i.e. sodium, magnesium, and calcium).

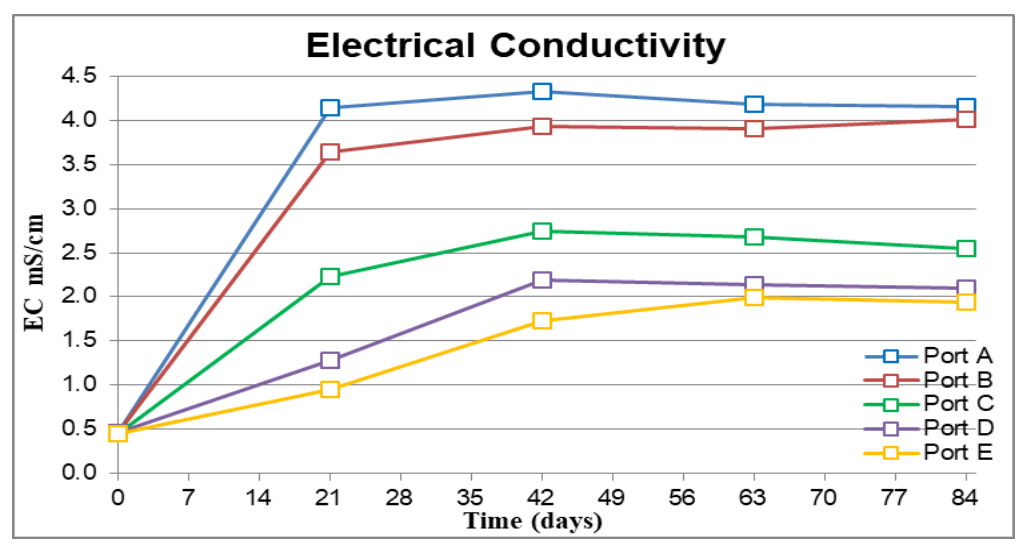

Fig (3) : EC in mS/cm (by three weeks moving average)

As per sodium adsorption ratio (SAR), the results of this study revealed that septic water has caused the (SAR) to decrease in all model Ports with significant decrease in Port C, Port D, and Port E suggesting that clay soil particles has been flocculated without increasing in infiltration rate (the model is fully saturated and flocculation increases water infiltration rate when soil gets dry). However, the increase in the concentrations of both of $\left(\mathrm{Ca}^{+2}+\mathrm{Mg}^{+2}\right)$ relative to $\left(\mathrm{Na}^{+}\right)$suggests that the flocculation was poor in Port A and Port B while in Port C, Port D, and Port E, the flocculation was strong because $\left(\mathrm{Ca}^{+2}\right)$ and $\left(\mathrm{Mg}^{+2}\right)$ are powerful flocculation cations that usually uses to improve the aggregate stability $\left(\mathrm{Ca}^{+2}\right.$ and $\mathrm{Mg}^{+2}$ are powerful flocculating cations stronger than $\left.\mathrm{Na}^{+}\right) \cdot\left(\mathrm{Ca}^{+2}\right)$ is stronger than $\left(\mathrm{Na}^{+}\right)$ by 43 times and $\left(\mathrm{Mg}^{+2}\right)$ is stronger than $\left(\mathrm{Na}^{+}\right)$by 27 times according to (Sumner and Naidu, 1998). See Fig.4. 

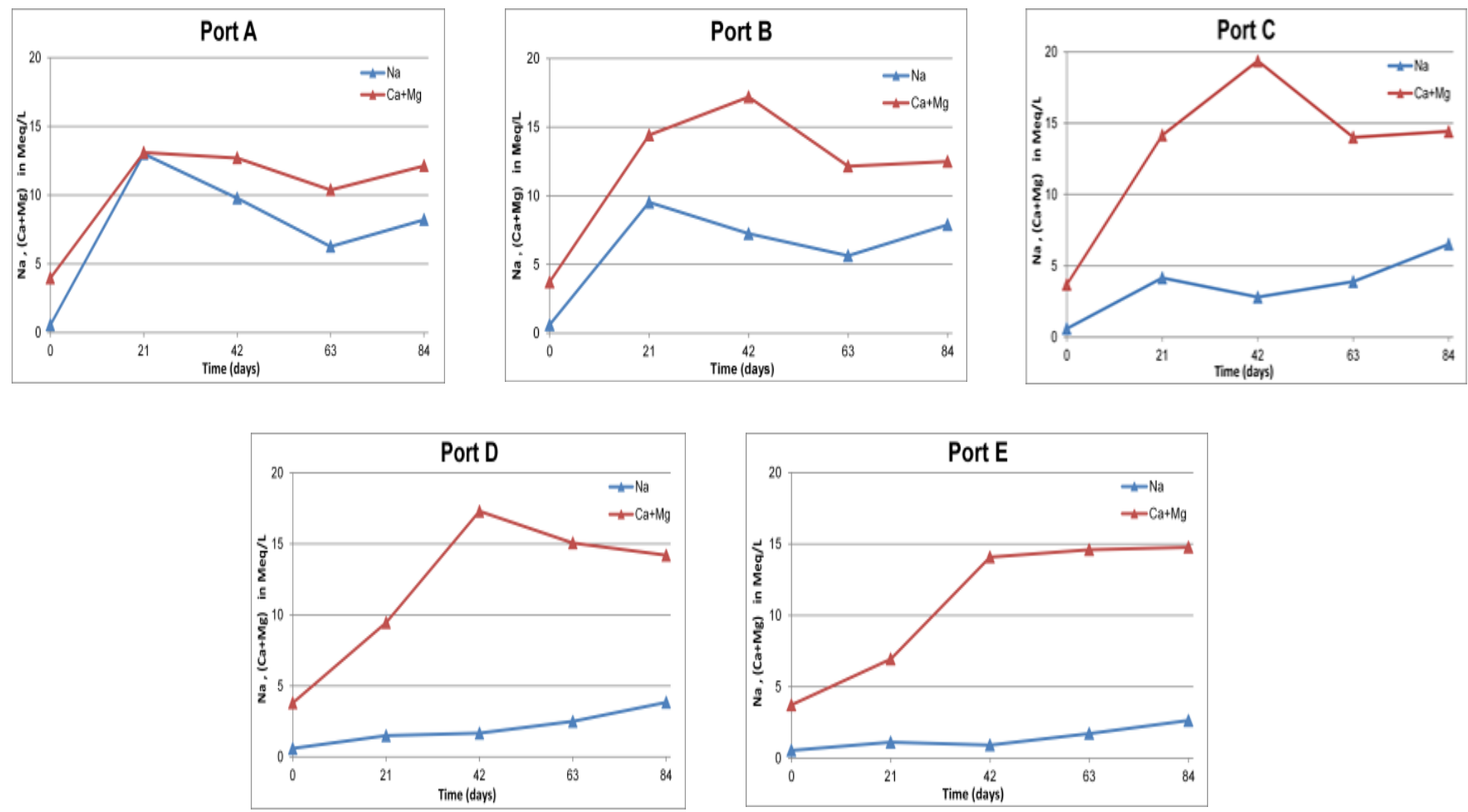

Fig (4) : Concentration of $\left(\mathrm{Na}^{+}\right)$and combined $\left(\mathrm{Ca}^{+2}+\mathrm{Mg}^{+2}\right)$ over all model running process

To assess the impact of septic water on soil physical properties (potential decrease in infiltration rates), the effect of water salinity (EC) together with its sodacity (SAR) was considered. A relationship between the salinity and sodicity of septic water has demonstrated as SAR $=0.9506{ }^{*}$ EC 0.7996 with $\mathrm{r}^{2}=0.988$. See Fig.5. For this study, analytical data of mean (EC) and mean (SAR) were plotted and showed that all were falling in the class of "No reduction in rate of infiltration". See

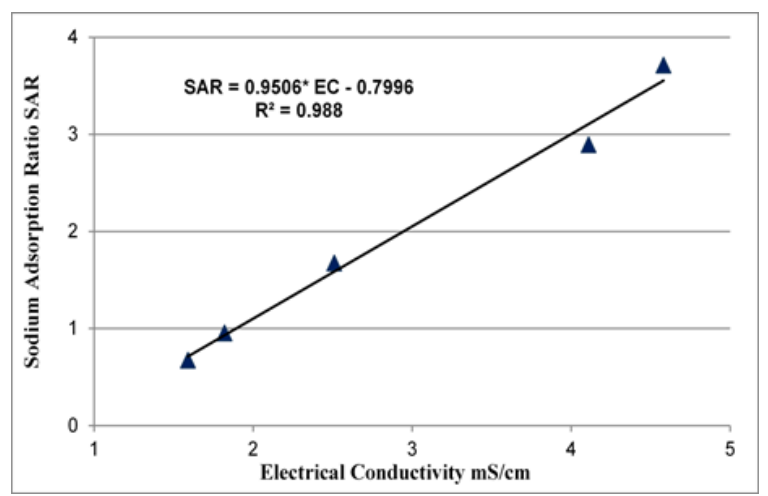

Fig (5) : The relationship between EC and SAR

With regards to residual sodium carbonate (RSC), the results of this study revealed that the mean values of (RSC) were: $2.58,-0.66,-1.74,-4.11$, and $-3.98 \mathrm{Meq} / \mathrm{L}$ for Port A through Port E respectively over all model running process. The positive value of (RSC) for Port A indicates that sodium is likely to accumulate (buildup) within clay soil (inside the model) while its negative values in Port B, Port C,
Fig.6. The mean (SAR) of Port A was within the range of 3-6 $(\mathrm{SAR}=3.71)$ and correspond to $(\mathrm{EC})>1.2(\mathrm{EC}=4.11$ $\mathrm{mS} / \mathrm{cm}$ ). Therefore there was no restriction on water use and no potential of water infiltration problems. Similarly, as the average (SAR) of all other Ports (i.e. Port B through Port E) were within the range of 0-3 and corresponded to $(E C)>0.7$, there was no potential of water infiltration problems according to (Ayers and Westcot,1985).

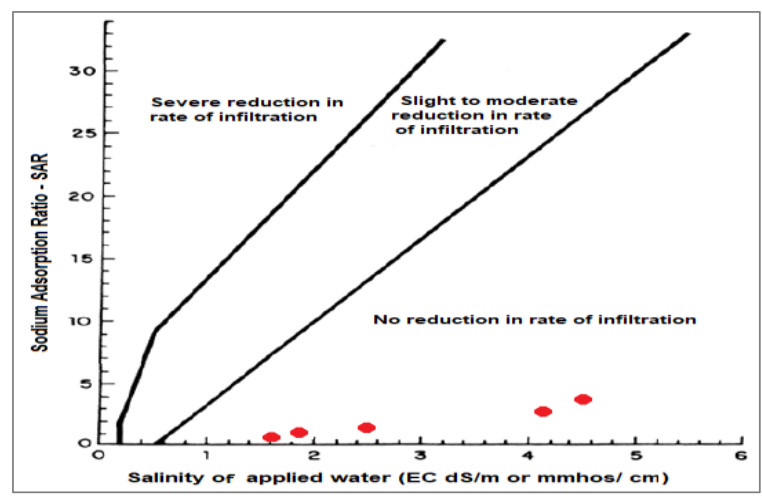

Fig (6) : Soil infiltration hazards of various EC/SAR applied water (After Hanson et al. 1999)

Port D, and Port E indicates that sodium is unlikely to accumulate and hence (SAR) decreases (Omotoso and Ojo, 2012). With regards to $\mathrm{pHc}$ and (adj. SAR), the results of this study revealed that the average values of $\mathrm{pHc}$ were: 6.44 , $6.41,6.33,6.51$, and 6.61 for Port A through Port E respectively over all model running process suggesting that lime $\left(\mathrm{CaCO}_{3}\right)$ has precipitated from septic water but, not 
from the clay soil it passed through (i.e. lime has accumulated within clay soil) as pHc below 8.4 indicates the tendency of lime $\left(\mathrm{CacO}_{3}\right)$ to precipitate from the water applied (Ayers and Westcot,1985). See Fig.7. This is the reason behind calcium accumulation within slit-Clay soil inside the model. The average values of (adj. SAR) were: $11.1,8.65,5.09,2.76$, and 1.90 for Port A through Port E

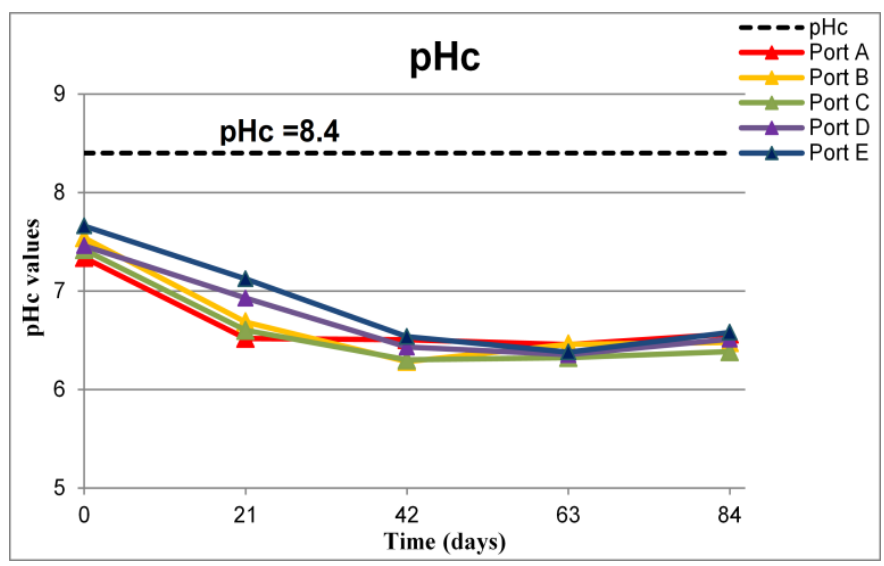

Fig (7) : pHc values (by three weeks moving average)

As per groundwater quality assessment, the results of microbiological analysis of this study revealed that highest level of both total and fecal coliform bacteria (>1650 MPN/100ml) were observed in Port A, Port B, and Port $C$ within four weeks of model running process, fluctuated thereafter between (0-300 MPN/100ml) in Port D while Port E observed clear. This suggests that any groundwater shallower than 31meter underground is fully contaminated by total and fecal coliform respectively over all model running process. It indicates that septic water causes a high hazard level of (adj. SAR) resulting in severe permeability problems in Port A with adj. SAR > 9 and high hazard level of (adj. SAR) with increasing problem in soil permeability in Port B of adj. SAR > 8.65 while other Ports were safe from (adj. SAR) hazard with no permeability problem according to (Ayers and Westcot, 1985). See Fig.8.

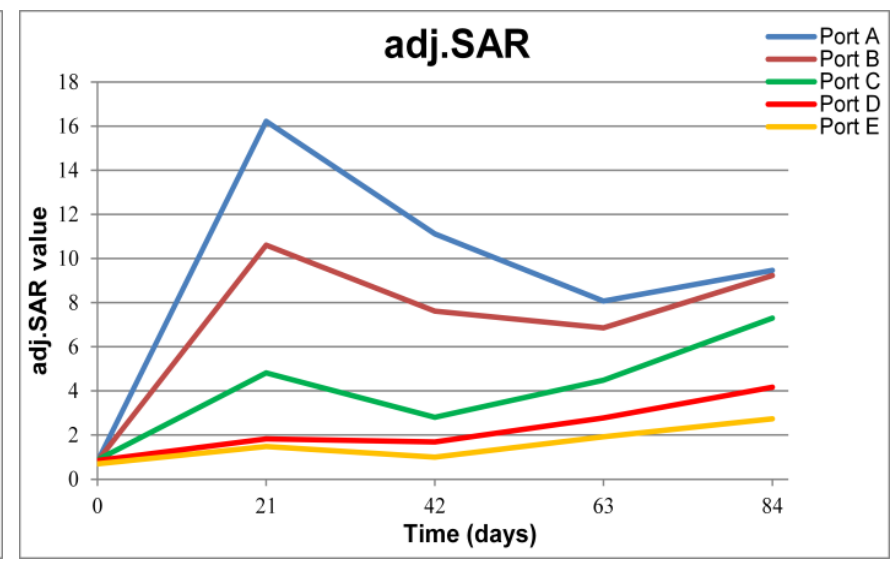

Fig (8) : SAR values (by three weeks moving average)

bacteria, any groundwater located at 41 meter underground is likely to be contaminated while groundwater deeper than 50 meter underground is safe from total and fecal coliform bacteria and likely to be cleared out through self-purification process within the clay soil profile. See Fig.9.

Note: Any MPN > 1600 was considered as 1650 and any $\mathrm{MPN}<2$ was considered as zero. 


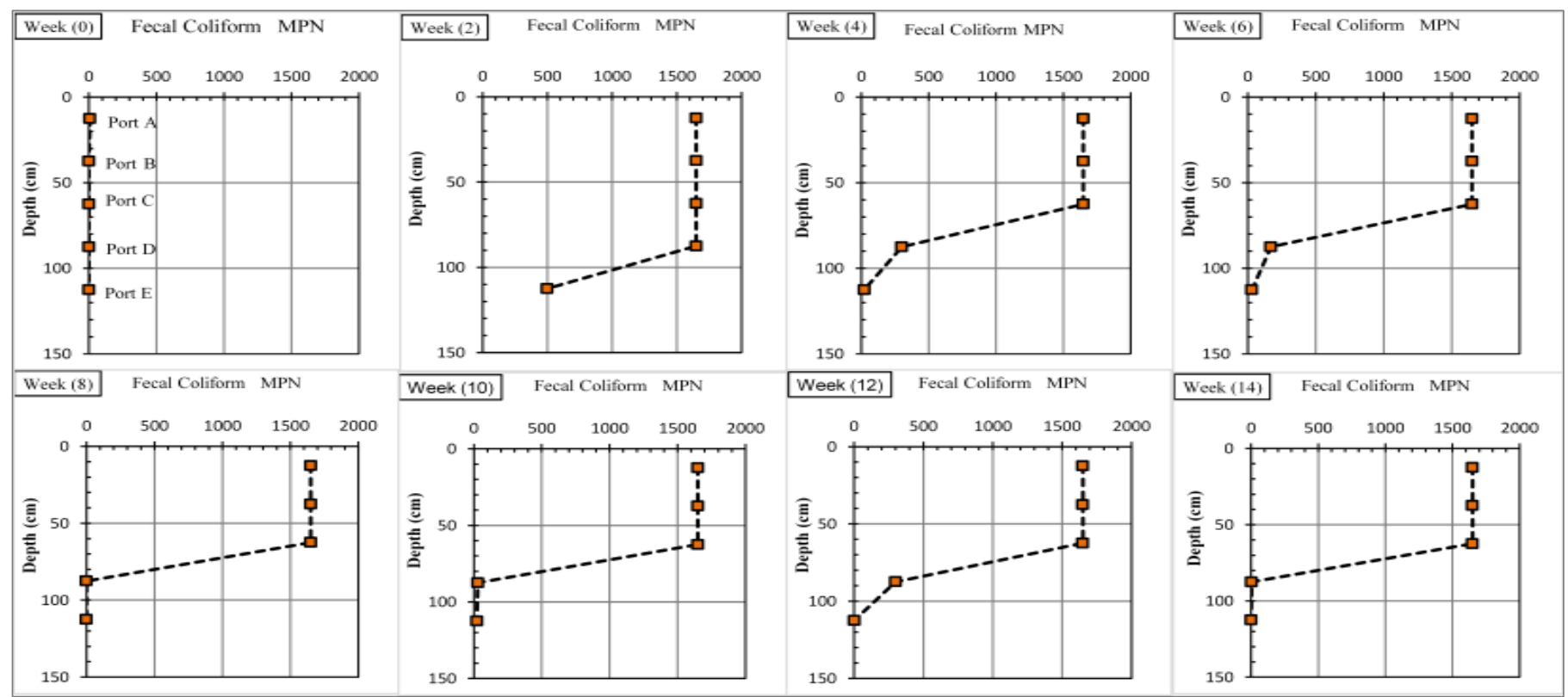

Fig(9) : Total and Fecal Coliform bacteria over all model running process

\section{Conclusion}

As septic water contains sufficient dissolved organic matters, inorganic constituents and salts, it presents salinity hazard that may contaminate the groundwater. As per this study, septic water caused the SAR to decrease and clay soil particles to flocculate but, without increasing the water infiltration rate (as the clay soil inside the model was maintained fully saturated and flocculation typically causes water infiltration rate to increase when the soil gets dry). Septic water has caused poor flocculation close to the source of supply (Port A and Port B) and strong flocculation as it goes deeper (i.e. Port C, Port D, and Port E), and this difference was attributed to the powerful flocculation cations $(\mathrm{Ca}+2)$ and $(\mathrm{Mg}+2)$ that usually uses to improve the aggregate soil stability. When the effect of water salinity (EC) considered together with its sodacity (SAR), analytical data showed no potential of water infiltration problems. Lime (Caco3) has precipitated within the model from the supplied septic water not from the clay soil it passed through. As a result of high (adj. SAR), septic water has caused permeability problems to Port A and Port B only. Therefore, highest level of both total and fecal coliform bacteria were observed in the first three Ports closest to the source of applied septic water. However, they started to disappear through natural biological self-purification processes within the soil itself.

Author Contributions

S.K. conceived and designed the experiments; S.K., L.A., and H.A. performed the experiments; S.K. analyzed the data; S.K., contributed reagents/materials/analysis tools; S.K. wrote the paper.

\section{References}

1. APHA (1995). Standard Methods for the Examination of Water and Wastewater, 19th ed., American Public Health Association, Washington, DC.

2. Ayers, R. \& Westcot, D. (1985). Water quality for agriculture. FAO Irrigation and drainage paper $29 \mathrm{Rev}$. 1. Food and Agricultural Organization. Rome,1, 74.

3. Blaylock, A. (1994). Soil salinity, salt tolerance, and growth potential of horticultural and landscape plants. University of Wyoming, Cooperative Extension Service, Department of Plant, Soil, and Insect Sciences, College of Agriculture.

4. Carrow, R. \& Duncan, R. (1998). Salt-affected turfgrass sites: assessment and management. John Wiley \& Sons. consequences (No. 631.416 S6).

5. Deshpande, S. \& Aher, K. (2012). Evaluation of groundwater quality and its suitability for drinking and agriculture use in parts of Vaijapur, District Aurangabad, MS, India.

6. Hanson, B., Grattan, S., \& Fulton, A. (1999). Agricultural salinity and drainage. University of California Irrigation Program, University of California, Davis.

7. Hillel, D. (2013). Introduction to soil physics. Academic press.

8. Holland, J. (1992). Development of a Comprehensive Modeling System for Remediation of Contaminated Groundwater.

9. Horneck, D., Ellsworth, J., Hopkins, B., Sullivan, D., \& Stevens, R. (2007). Managing salt-affected soils for crop production. [Covallis, Or.]: Oregon State University Extension Service.

10. Kochary, S.A. (2017). Experimental modeling to Investigate the transport of septic Tank contaminants in 
Duhok city, Iraqi Kurdistan Region (Ph.D. dissertation, University of Duhok, Duhok, Kurdistan Region of Iraq). 11. Kochary, S., Noori, B., \& Byl, T. (2017). Assessment of selected physico-chemical parameters of groundwater in direct contact with septic tanks: experimental modeling. Journal of Duhok University, 20(1), 231-240.

12. Naidu, R., Rengasamy, P., \& Sumner, M. (1995). Australian sodic soils: Distribution, properties and management. East Melbourne, VIC: CSIRO Australia.

13. Naseem, S., Hamza, S., \& Bashir, E. (2012). Assessment of geochemistry of soils for agriculture at Winder, Balochistan, Pakistan. In Water Quality, Soil and Managing Irrigation of Crops. InTech.

14. Omotoso, O., \& Ojo, O. (2012). Assessment of quality of river Niger floodplain water at Jebba, central Nigeria: implications for irrigation. Water Utility Journal, 4, 13-14.

15. Ryan, J., Estefan, G., \& Rashid, A. (2007). Soil and plant analysis laboratory manual. ICARDA.

16. Sumner, M. \& Naidu, R. (1998). Sodic soils distribution, properties, management, and environmental

17. USEPA, U. (1997). Exposure factors handbook. Office of Research and Development, Washington.

18. Yates, M. (1985). Septic tank density and groundwater contamination. Groundwater, 23(5), 586-591.

19. Zaidi, J., \& Pal, A. (2015). Influence of temperature on physico-chemical properties of freshwater ecosystem of Bundelkhand region of Uttar Pradesh, India. Int. J. Curr. Res. Chem. Pharma. Sci, 3, 1-8. 